\title{
Front Matter: Volume 7714
}

, "Front Matter: Volume 7714," Proc. SPIE 7714, Photonic Crystal Fibers IV, 771401 (4 June 2010); doi: 10.1117/12.868054

SPIE. Event: SPIE Photonics Europe, 2010, Brussels, Belgium 


\section{PROCEEDINGS OF SPIE}

\section{Photonic Crystal Fibers IV}

Kyriacos Kalli

Waclaw Urbanczyk

Editors

14-16 April 2010

Brussels, Belgium

Sponsored by

SPIE

Cosponsored by

B-PHOT—Brussels Photonics Team (Belgium) - Brussels-Capital Region (Belgium) • FWO_Fonds Wetenschappelijk Onderzoek (Belgium) • ICO_International Commission for Optics • Ville de Bruxelles (Belgium)

Cooperating Organisations

CBO-BCO (Belgium) • EOS—European Optical Society (Germany) • IET-The Institution of Engineering and Technology (United Kingdom) $\bullet$ IOP-Institute of Physics (United Kingdom)

Photonics4Life (Germany) - Photonics@be (Belgium) - Photonics 21 (Germany) - PromOptica (Belgium)

Published by

SPIE

Volume 7714

Proceedings of SPIE, 0277-786X, v. 7714 
The papers included in this volume were part of the technical conference cited on the cover and title page. Papers were selected and subject to review by the editors and conference program committee. Some conference presentations may not be available for publication. The papers published in these proceedings reflect the work and thoughts of the authors and are published herein as submitted. The publisher is not responsible for the validity of the information or for any outcomes resulting from reliance thereon.

Please use the following format to cite material from this book:

Author(s), "Title of Paper," in Photonic Crystal Fibers IV, edited by Kyriacos Kalli, Waclaw Urbanczyk, Proceedings of SPIE Vol. 7714 (SPIE, Bellingham, WA, 2010) Article CID Number.

ISSN 0277-786X

ISBN 9780819481870

Published by

SPIE

P.O. Box 10, Bellingham, Washington 98227-0010 USA

Telephone +1 3606763290 (Pacific Time) · Fax +1 3606471445

SPIE.org

Copyright (c) 2010, Society of Photo-Optical Instrumentation Engineers

Copying of material in this book for internal or personal use, or for the internal or personal use of specific clients, beyond the fair use provisions granted by the U.S. Copyright Law is authorized by SPIE subject to payment of copying fees. The Transactional Reporting Service base fee for this volume is $\$ 18.00$ per article (or portion thereof), which should be paid directly to the Copyright Clearance Center (CCC), 222 Rosewood Drive, Danvers, MA 01923. Payment may also be made electronically through CCC Online at copyright.com. Other copying for republication, resale, advertising or promotion, or any form of systematic or multiple reproduction of any material in this book is prohibited except with permission in writing from the publisher. The CCC fee code is 0277-786X/10/\$18.00.

Printed in the United States of America.

Publication of record for individual papers is online in the SPIE Digital Library.

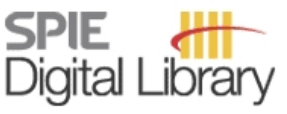

SPIEDigitalLibrary.org

Paper Numbering: Proceedings of SPIE follow an e-First publication model, with papers published first online and then in print and on CD-ROM. Papers are published as they are submitted and meet publication criteria. A unique, consistent, permanent citation identifier (CID) number is assigned to each article at the time of the first publication. Utilization of CIDs allows articles to be fully citable as soon they are published online, and connects the same identifier to all online, print, and electronic versions of the publication. SPIE uses a six-digit CID article numbering system in which:

- The first four digits correspond to the SPIE volume number.

- The last two digits indicate publication order within the volume using a Base 36 numbering system employing both numerals and letters. These two-number sets start with 00, 01, 02, 03, 04 , $05,06,07,08,09,0 A, 0 B \ldots$. OZ, followed by 10-1Z, 20-2Z, etc.

The CID number appears on each page of the manuscript. The complete citation is used on the first page, and an abbreviated version on subsequent pages. Numbers in the index correspond to the last two digits of the six-digit CID number. 


\section{Contents}

ix Conference Committee

xi Introduction

PHOTONIC CRYSTAL FIBRE SENSORS: JOINT SESSION WITH CONFERENCE 7726

771402 Bragg fibre for sensing applications [7714-32]

O. Frazão, J. M. Baptista, J. L. Santos, INESC Porto (Portugal); P. Roy, R. Jamier, S. Février, XLIM, CNRS, Univ. de Limoges (France)

771403 Sensing characteristics of long period gratings and rocking filters based on highly birefringent boron-doped photonic crystal fiber and fabricated by a $\mathrm{CO}_{2}$ laser [7714-33] J. P. Carvalho, INESC Porto (Portugal) and Univ. do Porto (Portugal);

G. Statkiewicz-Barabach, A. Anuszkiewicz, Wroclaw Univ. of Technology (Poland); J. M. Baptista, INESC Porto (Portugal) and Univ. da Madeira (Portugal); O. Frazão, INESC Porto (Portugal); J. Wojcik, Univ. Marii Curie-Skłodowskiej (Poland); J. L. Santos, INESC Porto (Portugal) and Univ. do Porto (Portugal); W. Urbanczyk, Wroclaw Univ. of Technology (Poland)

\section{NONLINEAR AND ACTIVE SILICA PCF}

771404 Adjustable supercontinuum laser source with low coherence length and low timing jitter [7714-01]

M. Andreana, XLIM, CNRS and Univ. de Limoges (France); A. Bertrand, Y. Hernandez, Multitel A.S.B.L. (Belgium); P. LeprouX, V. Couderc, XLIM, CNRS and Univ. de Limoges (France); S. Hilaire, G. Huss, Leukos (France); D. Giannone, Multitel A.S.B.L. (Belgium); A. Tonello, A. Labruyère, XLIM, CNRS and Univ. de Limoges (France); N. Rongeat, P. Nérin, Horiba Medical (France)

771405 Amplification of femtosecond pulses in large mode area Bragg fibers [7714-02] D. A. Gaponov, S. Février, P. Roy, XLIM, CNRS and Univ. de Limoges (France); M. Hanna, D. N. Papadopoulos, F. Druon, L. Daniault, P. Georges, Lab. Charles Fabry de l'Institut d'Optique, CNRS, Univ. Paris-Sud (France); M. E. Likhachev, Fiber Optics Research Ctr. (Russian Federation); M. Y. Salganskii, M. V. Yashkov, Institute of Chemistry of High Purity Substances (Russian Federation)

771406 Effect of inhomogeneities on backward and forward Brillouin scattering in photonic crystal fibers [7714-03]

B. Stiller, M. Delqué, M. W. Lee, Institut FEMTO-ST, Univ. de Franche-Comté (France);

S. Foaleng Mafang, J.-C. Beugnot, École Polytechnique Fédérale de Lausanne (Switzerland); A. Kudlinski, Lab. de Physique des Lasers Atomes et Molécules, CNRS, IRCICA (France); L. Thévenaz, École Polytechnique Fédérale de Lausanne (Switzerland); H. Maillotte, T. Sylvestre, Institut FEMTO-ST, Univ. de Franche-Comté (France) 
771407 Deep ultraviolet supercontinuum generation in optical nanofibers by femtosecond pulses at 400-nm wavelength (Best Student Paper Award) [7714-04]

A. M. Heidt, IPHT Jena (Germany) and Stellenbosch Univ. (South Africa); A. Hartung,

H. Bartelt, IPHT Jena (Germany)

771408 Luminescence of PbS quantum dots on a silica microstructured fiber [7714-05]

L. C. Barbosa, E. F. Chillcce, C. M. Cordeiro, Univ. Estadual de Campinas (Brazil)

NONLINEAR CHALCOGENIDE PCF

771409 Experimental observation of infrared spectral enlargement in $\mathrm{As}_{2} \mathrm{~S}_{3}$ suspended core microstructured fiber (Invited Paper) [7714-06]

M. El-Amraoui, J. Fatome, J. C. Jules, B. Kibler, G. Gadret, Lab. Interdisciplinaire Carnot de Bourgogne, CNRS, Univ. de Bourgogne (France); I. Skripatchev, Y. Messadeq, UNESP (Brazil); G. Renversez, Institut Fresnel, CNRS, Univ. Aix-Marseille (France); M. Szpulak, Wroclaw Univ. of Technology (Poland); J. Troles, Sciences Chimiques de Rennes, CNRS, Univ. de Rennes 1 (France); L. Brilland, Plate-forme d'Étude et de Recherche sur les Fibres Optiques Spéciales (France); F. Smektala, Lab. Interdisciplinaire Carnot de Bourgogne, CNRS, Univ. de Bourgogne (France)

$7714 \mathrm{OB}$ Frequency conversion from near-infrared to mid-infrared in highly nonlinear optical fibres [7714-08]

N. Ducros, XLIM, CNRS and Univ. de Limoges (France); F. Morin, Lab. Charles Fabry de I'Institut d'Optique, Univ. Paris-Sud (France); K. Cook, The Univ. of Sydney (Australia); A. Labruyère, S. Février, G. Humbert, XLIM, CNRS and Univ. de Limoges (France); F. Druon, M. Hanna, P. Georges, Lab. Charles Fabry de l'Institut d'Optique, Univ. Paris-Sud (France); J. Canning, The Univ. of Sydney (Australia); R. Buczynski, Univ. of Warsaw (Poland); D. Pysz, R. Stepien, Institute of Electronic Materials Technology (Poland)

7714 OC The tellurite highly nonlinear microstructured fibers for THG and SC generations [7714-09] M. Liao, C. Chaudhari, G. Qin, X. Yan, T. Suzuki, Y. Ohishi, Toyota Technological Institute (Japan)

POLYMER PCF

7714 OD Multiplexed FBG sensor recorded in multimode microstructured polymer optical fibre (Invited Paper) [7714-10]

I. P. Johnson, D. J. Webb, Aston Univ. (United Kingdom); K. Kalli, Cyprus Univ. of Technology

(Cyprus); M. C. J. Large, A. Argyros, The Univ. of Sydney (Australia)

7714 OF Investigation of sensing properties of microstructured polymer optical fibres [7714-12] J. Witt, M. Steffen, M. Schukar, K. Krebber, Bundesanstalt für Materialforschung und -prüfung (Germany)

7714 OG Measurements of stress-optic coefficient and Young's modulus in PMMA fibers drawn under different conditions [7714-13]

M. K. Szczurowski, T. Martynkien, G. Statkiewicz-Barabach, Wroclaw Univ. of Technology (Poland); L. Khan, D. J. Webb, Aston Univ. (United Kingdom); C. Ye, J. Dulieu-Barton, Univ. of Southampton (United Kingdom); W. Urbanczyk, Wroclaw Univ. of Technology (Poland) 
$7714 \mathrm{OH}$ Theory of second-harmonic generation in silica nanowires (Invited Paper) [7714-14] J. Laegsgaard, Technical Univ. of Denmark (Denmark)

771401 Higher-order mode suppression in rod-type photonic crystal fibers with sectioned doping and enlarged core [7714-15]

F. Poli, E. Coscelli, D. Passaro, A. Cucinotta, S. Selleri, Univ. degli Studi di Parma (Italy);

J. Laegsgaard, Technical Univ. of Denmark (Denmark); J. Broeng, Crystal Fibre A/S (Denmark)

7714 OJ Single mode and single polarization operation in photonic crystal fibers [7714-16] B. M. A. Rahman, N. Kejalakshmy, A. Agrawal, M. Uthman, K. T. V. Grattan, The City Univ. London (United Kingdom)

7714 OK Influence of transverse perturbation of soliton propagation direction on laser radiation evolution along the layered medium [7714-17]

V. A. Trofimov, T. M. Lysak, O. V. Matusevich, Lomonosov Moscow State Univ. (Russian Federation)

\section{MODELLING AND NUMERICAL ANALYSIS OF PCF II}

$7714 \mathrm{ON}$ Optimal design of broadband photonic crystal fibre long-period gratings for evanescent absorption sensing [7714-20]

J. Kanka, Institute of Photonics and Electronics (Czech Republic)

\section{DEVICE DEVELOPMENT BASED ON PCF}

7714 OP Short wavelength (UV + VIS) guidance in kagomé lattice hollow core photonic crystal fibre (Invited Paper) [7714-22]

S. Février, B. Beaudou, XLIM, CNRS, Univ. de Limoges (France)

$77140 Q \quad$ Photonic crystal fiber filled with a high index electro-optic polymer [7714-23]

M. Balakrishnan, R. Spittel, J. Kobelke, K. Schuster, V. Reichel, H. Bartelt, IPHT Jena (Germany)

7714 OS UV Bragg grating inscription in germanium-doped photonic crystal fibers [7714-25]

T. Geernaert, Brussels Photonics Team B-PHOT, Vrije Univ. Brussel (Belgium); M. Becker, IPHT Jena (Germany); P. Mergo, Univ. Marii Curie-Skłodowskiej (Poland); T. Nasilowski, Brussels Photonics Team B-PHOT, Vrije Univ. Brussel (Belgium); J. Wojcik, Univ. Marii Curie-Skłodowskiej (Poland); W. Urbanczyk, Wroclaw Univ. of Technology (Poland); M. Rothhardt, IPHT Jena (Germany); C. Chojetzki, FBGS Technologies GmbH (Germany); H. Bartelt, IPHT Jena (Germany); F. Berghmans, H. Thienpont, Brussels Photonics Team B-PHOT, Vrije Univ. Brussel (Belgium) 
$77140 U$ Demonstration of multimode interference effect for PCF connectors (Invited Paper) [7714-27] C. D. Stacey, BAE Systems Advanced Technology Ctr. (United Kingdom); C. Clarke, Imperial College London (United Kingdom); R. G. Clarke, D. W. Charlton, BAE Systems Advanced Technology Ctr. (United Kingdom)

7714 OV Sagnac interferometer based on a suspended twin-core fibre [7714-28] O. Frazão, INESC Porto (Portugal); J. M. Baptista, INESC Porto (Portugal) and Univ. da Madeira (Portugal); J. L. Santos, INESC Porto (Portugal) and Univ. do Porto (Portugal); J. Kobelke, K. Schuster, IPHT Jena (Germany)

7714 OW Modal decomposition for photonic crystal fibers using computer-generated holograms [7714-30]

O. A. Schmidt, D. Flamm, M. Duparré, Friedrich-Schiller-Univ. Jena (Germany)

$77140 \mathrm{X}$ Optical, thermal, and mechanical characterization of photonic crystal fibers: results and comparisons [7714-31]

K. Borzycki, National Institute of Telecommunications (Poland); J. Kobelke, K. Schuster, IPHT Jena (Germany); J. Wójcik, Univ. Marii Curie-Skłodowskiej (Poland)

\section{POSTER SESSION}

7714 OY The impact of ring core on chromatic dispersion of photonic quasicrystal fiber [7714-18] S. Kim, C-S.. Kee, Gwangju Institute of Science and Technology (Korea, Republic of); J. Park, S. Lee, K. Oh, Yonsei Univ. (Korea, Republic of); C. G. Lee, Chosun Univ. (Korea, Republic of)

$77140 Z$ Broad spectral range measurement of chromatic dispersion of polarization modes in holey fibers by interferometric techniques [7714-29]

P. Hlubina, D. Ciprian, M. Kadulová, Technical Univ. of Ostrava (Czech Republic);

T. Martynkien, W. Urbańczyk, Wroclaw Univ. of Technology (Poland)

771410 High resolution pulse distortion precompensation in nanosecond ytterbium-doped fiber amplifiers [7714-34] L. Lago, Commissariat à l'Énergie Atomique (France); A. Mussot, M. Douay, IRCICA, CNRS, Univ. des Sciences et Technologies de Lille (France); E. Hugonnot, Commissariat à l'Énergie Atomique (France)

771411 Tunable liquid crystal filled photonic crystal fiber coupler [7714-35] K. R. Khan, T. J. Hall, Univ. of Ottawa (Canada)

771413 Large-mode-area Bragg fiber with microstructured core for suppression of high-order modes [7714-37]

S. S. Aleshkina, M. E. Likhachev, A. D. Pryamikov, D. A. Gaponov, A. N. Denisov, S. L. Semjonov, M. M. Bubnov, Fiber Optics Research Ctr. (Russian Federation); M. Yu. Salganskii, A. N. Guryanov, Institute of High Purity Substances (Russian Federation)

771414 Arc fusion splicing of photonic crystal fibers to standard single mode fibers [7714-38] K. Borzycki, National Institute of Telecommunications (Poland); J. Kobelke, K. Schuster, IPHT Jena (Germany); J. Wójcik, Univ. Marii Curie-Skłodowskiej (Poland) 
771415 Guiding properties of kagome-lattice hollow-core fibers [7714-39]

E. Coscelli, F. Poli, D. Passaro, A. Cucinotta, S. Selleri, Univ. degli Studi di Parma (Italy)

771416 Dispersion tailored microstructured fibers: core dopant effects [7714-40]

J. Kobelke, K. Schuster, R. Spittel, A. Hartung, A. Schwuchow, J. Kirchhof, H. Bartelt, IPHT Jena (Germany)

Author Index 
Downloaded From: https://www.spiedigitallibrary.org/conference-proceedings-of-spie on 26 Apr 2023

Terms of Use: https://www.spiedigitallibrary.org/terms-of-use 


\title{
Conference Committee
}

\author{
Symposium Chairs
}

Francis Berghmans, Vrije Universiteit Brussel (Belgium)

Ronan Burgess, European Commission (Belgium)

Jürgen Popp, Institut für Photonische Technologien e.V. (Germany)

Peter Hartmann, SCHOTT AG (Germany)

Hugo Thienpont, Vrije Universiteit Brussel (Belgium)

Conference Chairs

Kyriacos Kalli, Cyprus University of Technology (Cyprus)

Waclaw Urbanczyk, Wroclaw University of Technology (Poland)

Program Committee

Hartmut Bartelt, Institut für Photonische Technologien e.V. (Germany)

Francis Berghmans, Vrije Universiteit Brussel (Belgium)

Benjamin J. Eggleton, The University of Sydney (Australia)

Sébastien Février, Université de Limoges (France)

Jiri Kanka, Institute of Photonics and Electronics (Czech Republic)

Jonathan C. Knight, University of Bath (United Kingdom)

Hanne Ludvigsen, Helsinki University of Technology (Finland)

B. M. Azizur Rahman, The City University (United Kingdom)

Karsten Rottwitt, Technical University of Denmark (Denmark)

Kay Schuster, Institut für Photonische Technologien e.V. (Germany)

Dmitry V. Skryabin, University of Bath (United Kingdom)

David J. Webb, Aston University (United Kingdom)

Alexei M. Zheltikov, Lomonosov Moscow State University

(Russian Federation)

Session Chairs

Photonic Crystal Fibre Sensors: Joint Session with Conference 7726

Stavros Pissadakis, Foundation for Research and Technology-Hellas

(Greece)

Hartmut Bartelt, Institut für Photonische Technologien e.V. (Germany)

1 Nonlinear and Active Silica PCF

Kyriacos Kalli, Cyprus University of Technology (Cyprus)

2 Nonlinear Chalcogenide PCF

Kay Schuster, Institut für Photonische Technologien e.V. (Germany) 
3 Polymer PCF

Jiri Kanka, Institute of Photonics and Electronics (Czech Republic)

$4 \quad$ Modelling and Numerical Analysis of PCF I

Sébastien Février, Université de Limoges (France)

$5 \quad$ Modelling and Numerical Analysis of PCF II

B. M. Azizur Rahman, The City University (United Kingdom)

6 Device Development Based on PCF

David J. Webb, Aston University (United Kingdom)

$7 \quad$ Physical Properties of PCF

Waclaw Urbanczyk, Wroclaw University of Technology (Poland) 


\section{Introduction}

It has been nearly twenty years since the conception of photonic crystal fibers, as devised by Philip St. J. Russell in unpublished work dating to 1991. That work was a development of the photonic crystal ideas of Yablonovich and John who published two milestone papers on photonic crystals in 1987. The photonic crystal fiber (PCF) has given the field of fiber optics a newfound resurgence, resulting in revolutionary research and practical breakthroughs that would have proven otherwise impossible with conventional optical fibers; these include octavespanning light continua, air guidance of light with low loss over several kilometers, and endlessly single-mode fiber operating over several hundred nanometers. The unusual confinement characteristics of PCF have resulted in their use in applications such as fiber-optic communications and sensing, fiber lasers, nonlinear devices, high-power transmission, and highly sensitive gas sensors, amongst others.

The term photonic crystal fiber has been used extensively to cover a class of optical fibers that include the photonic band gap fiber (with light confinement through the band gap effect), hole-assisted or microstructure fiber (guiding light through a conventional high-index core modified by the presence of air holes), and Bragg fiber (photonic band gap fiber formed using multilayer, concentric rings).

This fourth conference in the series on photonic crystal fibers reports some of the latest developments of PCF. The strength of photonic crystal fiber relates to its versatility and flexibility in terms of fiber geometry and material used. The fabrication and design of PCF is reported for nonlinear and active silica and chalcogenide fibres and the latest developments of polymer based PCF, along with the characterization of PCF utilizing spectral interferometry. Developments of fiber-based light sources are supported by advances in super continuum generation through non-linear mixing in index-guiding crystal fibers. New device applications are demonstrated for Bragg and long period gratings in doped and infiltrated fibers. The stability of grating structures is examined as are sensing of external parameters such as temperature and strain. Great strides have been made in the modeling of PCF, and special sessions are devoted to the development of modeling and numerical analysis. The conference has several invited papers and a joint session held with the Optical Sensing and Detection Conference.

We hope the reader will find the conference proceedings as interesting as our recent meeting in Brussels.

\section{Kyriacos Kalli Wacław Urbańczyk}


Downloaded From: https://www.spiedigitallibrary.org/conference-proceedings-of-spie on 26 Apr 2023

Terms of Use: https://www.spiedigitallibrary.org/terms-of-use 